\title{
Improving labour standards for migrant domestic workers in Qatar: A return to labour rights
}

\author{
ARISHA ARIF
}

\section{Abstract}

The human impact of development in the Middle East is acutely borne by the migrant workforce that sustains it. This paper takes Qatar as a case study to analyse the usefulness of labour rights and human rights in protecting migrant workers. In Qatar, migrant workers are excluded from national law and relying on human rights is, for them, futile, with many protections reserved for citizens. Recourse must be had to something else to protect them. This paper argues that the International Labour Organization (ILO) and a bottom-up approach underlying labour rights can better protect migrant workers in such settings. To do this, it looks at the ILO's activities and successes in protecting migrant workers to date, and the futility of international human rights in a country that consistently objects to and rejects them. The paper ends by analysing the ILO's more recent moves towards human rights, and argues against them, instead pushing for a return to pure labour rights that emphasises worker agency over state control.

\section{Introduction}

Economic development throughout the Gulf Cooperative Council (GCC) is tainted by the treatment of the migrant workforce that sustains it. Kuwait, Bahrain, Oman, Qatar, Saudi Arabia, and the United Arab Emirates have all attracted international attention for their poor treatment of migrant workers. ${ }^{1}$ Many of these states attempt to avoid responsibility for these workers by excluding them

1 Saroj Pathirana, 'Kuwait's abused domestic workers have "nowhere to turn”, $B B C$ News (online), 13 October 2010, www.bbc.com/news/world-south-asia-11444167; 'Bahrain: Abuse of Migrant Workers Despite Reforms', Human Rights Watch, 1 October 2012, www.hrw.org/news/2012/09/30/bahrain-abuse-migrant-workers-despitereforms; 'UN expert on human trafficking calls on Oman to do more to help victims', United Nations News Centre, 8 November 2006, www.un.org/apps/news/story.asp?NewsID=20537\#.VEywwY4isWY; Pete Pattisson, 'Revealed: Qatar's World cup "slaves", The Guardian (online), 26 September 2013, www.theguardian.com/ world/2013/sep/25/revealed-qatars-world-cup-slaves; William Davison, 'Ethiopia Workers Return from Saudi Arabia Telling of Abuse', Bloomberg, 13 December 2013, www.bloomberg.com/news/2013-12-12/ethiopian- 
from their protective labour legislation. Qatar, in particular, has occupied much of the international spotlight ahead of the 2022 FIFA World Cup, with its labour law among the most restrictive in the region. ${ }^{2}$ Here, all migrant workers are regulated through the kafala system of employer-employee relations, and are excluded from key aspects of the national labour law. The vulnerability this creates is heightened for migrant domestic workers who are excluded from all labour law while working in private and closed settings.

This essay will use migrant domestic workers in Qatar as a case study to argue against a human rights-based approach to the protection of these workers and the assertion of their rights. The International Labour Organization (ILO) has increasingly adopted a human rights approach in regulating labour, most recently that of domestic workers. This approach jeopardises the practical achievements of international labour law, which is better positioned to obtain protection for those workers that need it most. Accordingly, this paper advocates a return to a pure labour rights approach that emphasises worker agency, and, ultimately, better achieves what the corpus of international human rights sets out to secure.

\section{Creating 'bare life'}

Around the world, migrant workers are 'a minority group whose transnational identity works against them.' ${ }^{3}$ They are an important part of sending states' trade relationships, and present a source of labour to receiving states without the burden of rights and citizenship. ${ }^{4}$ Neither receiving states nor sending states have a great interest in strengthening migrant workers' rights. This is clear in the transnational regulation of labour, which has rarely been protective of workers, instead focusing on managing migration. ${ }^{5}$ However, the disinterest towards migrant workers is most apparent in states that have entirely de-subjectified them through exemption from labour legislation and the protections it offers. In Qatar, this is made possible in two key ways.

\footnotetext{
migrant-workers-return-from-saudi-with-tales-of-abuse.html; David Batty, 'Conditions for Abu Dhabi’s migrant workers "shame the west”, The Guardian (online), 22 December 2013, www.theguardian.com/world/2013/dec/22/ abu-dhabi-migrant-workers-conditions-shame-west.

2 'Building a Better World Cup: Protecting Migrant Workers in Qatar Ahead of FIFA 2022' (Report, Human Rights Watch, June 2012) 51 (HRW Report).

3 Ethel Tungohan, 'International Approaches to Governing International Migrants, Ethnicity, and Gender: An Intersectional Analysis of Migrants' Rights' in Will Kymlicka and Jane Boulden (eds), International Approaches to Governing Ethnic Diversity (Oxford University Press, 2012).

4 Ibid.

5 Adele Blackett, 'The Space Between Us: Migrant Domestic Workers as a Nexus between International Labour Standards and Trade Policy' in Daniel Drache and Les Jacobs (eds), Linking Global Trade and Human Rights: New Policy Space in Hard Economic Times (Cambridge University Press, 2014) 259, 265.
} 
Firstly, the kafala system of employer-employee relations severely limits migrant workers' freedom and mobility. ${ }^{6}$ The kafala system, used in varying forms across GCC countries, regulates the sponsorship, employment and residence of migrant workers, and places their legal status under the responsibility of their employers. ${ }^{7}$ Migrant workers employed in the kafala system must possess exit permits to leave the country, which they are only able to obtain from the employers that have sponsored them. ${ }^{8}$ While in the country, the consent of a present employer is needed before any change of employment can take place. ${ }^{9}$ This leaves migrant workers particularly vulnerable to exploitation in situations of low wages, insecurity, poor working conditions, and a lack of unionisation. ${ }^{10}$

Secondly, migrant workers are given limited protections under the national labour law. ${ }^{11}$ All private employees are given minimum protections insofar as the law requires that they are paid annual leave and sick leave; sets requirements for their health and safety; requires the timely payment of wages; prohibits recruiters from receiving recruitment fees; and regulates the disciplinary power of the employer. ${ }^{12}$ These protections are poorly enforced, and further limited by the kafala system. ${ }^{13}$

To add to this, migrant workers are explicitly denied the freedom of association, and the right to collective bargaining, both of which have been identified by the ILO as core international labour rights. ${ }^{14}$ The law prevents foreign workers from joining workers' committees or the 'General Union of the Workers of Qatar' by stipulating that 'membership ... shall be confined to the Qatari workers' ${ }^{15}$ Workers who wish to strike are able to do so only after 'amicable settlement between the workers and employer by conciliation or arbitration ... becomes impossible'. ${ }^{16}$

Of the myriad ways in which migrant workers have been denied protection, the explicit removal of migrant domestic workers from the labour law altogether ${ }^{17}$ is the most concerning. Migrant domestic workers labour in semi-private spheres in closed households, where they are especially vulnerable to abuse. ${ }^{18}$ Human rights groups have confirmed that migrant domestic workers in Qatar constitute 'the most

6 Law No. 4 of 2009 Regarding Regulation of the Expatriates Entry, Departure, Residence and Sponsorship (Qatar) 29 March 2009 (Law No. 4).

7 Ibid ch 4, art 18; ibid ch 3, art 15; ibid ch 3 .

8 Ibid ch 2, art 3; ibid ch 4, art 18; ibid ch 1, art 1 (definition of 'residence sponsor').

9 Ibid ch 4 , art 22.

10 See e.g. HRW Report.

11 Law No. 14 of 2004 On the Promulgation of Labour Law (Qatar) 19 May 2004 (Law No. 14).

12 Ibid pt 6, art 72; ibid pt 7, art 79; ibid pt 10; ibid pt 6, art 66; ibid pt 3, art 33; ibid pt 5, arts 59-60.

13 See HRW Report, above n 10.

14 International Labour Organization Declaration on Fundamental Principles and Rights at Work and its Follow-up, International Labour Conference, 86th sess (18 June 1998) arts 2(a)-(b) (Fundamental Declaration).

15 Law No. 14, pt 12, art 116.

16 Ibid pt 12, art 120.

17 Ibid pt 3, art 1.

18 Ibid. 
vulnerable category of workers'. ${ }^{19}$ The situation of these workers finds familiarity in Giorgio Agamben's analysis of homo sacer, a figure of Roman law included in society through exclusion that reduced him to 'bare life'; that is, life without the politicisation and enjoyment of rights that characterises the citizen's life. ${ }^{20}$

\section{The illusion of human rights}

The significance of these workers' exclusion is illuminated by Hannah Arendt's famous claim that any entitlement to rights is granted through participation in the public political sphere-rights that are seen as universal (i.e. human rights) belong to those that are absent from this sphere. ${ }^{21}$ Agamben advanced Arendt's concern when he observed that 'so-called sacred and inalienable human rights are revealed to be without any protection precisely when it is no longer possible to conceive of them as rights of the citizens of a state'. ${ }^{22}$ The migrant domestic workers reduced to 'bare life' possess human rights, however, their exclusion from the state means that they cannot enjoy these rights. For these workers, human rights lack protection and, subsequently, any tangible meaning.

Within the international human rights law framework, Qatar does not need to ensure this protection. Qatar's international human rights obligations are limited given it has not ratified key international human rights instruments, including the International Covenant on Civil and Political Rights (ICCPR) and the International Covenant on Economic, Social and Cultural Rights (ICESCR) ${ }^{23}$ Human rights bodies exist to monitor compliance with international obligations, and can do little when those obligations simply do not exist for a given state. The current international human rights regime is a development of the Western liberal interest in the rights of the individual, which places its focus on the accountability of states. ${ }^{24}$ This topdown approach sustains the 'lingering presence' of the nation-state, and affirms the sovereign power necessary for making 'bare life' possible..$^{25}$ In particular, it is

19 Qatar National Human Rights Committee, February 2014 quoted in 'The Dark Side of Migration: Spotlight on Qatar's Construction Sector Ahead of the World Cup' (Report, Amnesty International, 2013) 23.

20 Alison Mountz, 'Where asylum-seekers wait: feminist counter-topographies of sites between states' (2011) 18(3) Gender, Place and Culture, 381, 386; see also Giorgio Agamben, Homo Sacer: Sovereign Power and Bare Life (Stanford University Press, 1998).

21 Cited in Jessica Whyte, 'Particular Rights and Absolute Wrongs: Giorgio Agamben on Life and Politics' (2009) 20 Law Critique 147, 150.

22 Giorgio Agamben, Homo Sacer: Sovereign Power and Bare Life (Stanford University Press, 1998) 126.

23 International Covenant on Civil and Political Rights, opened for signature 19 December 1966, 999 UNTS 171 (entered into force 23 March 1976) (ICCPR); International Covenant on Economic Social and Cultural Rights, opened for signature 19 December 1966, 993 UNTS 3 (entered into force 3 January 1976) (ICESCR).

24 David Kennedy, 'The International Human Rights Movement: Part of the problem?' (2002) 14 Harvard Human Rights Journal 101, 109.

25 Richard Ek, 'Giorgio Agamben and the Spatialities of the Camp: An introduction'(2006) Journal Compilation - Swedish Society for Anthropology and Geology 369; Agamben, cited in Whyte, above n 21, 153. 
an approach that states, including Qatar, can quite easily refuse to take. The same cannot as easily be said of another set of rights that migrant domestic workers acquire and possess: labour rights. ${ }^{26}$

\section{How are labour rights different?}

The short answer is: increasingly by little. Historically, movements for labour rights and human rights have been parallel, but distinctly separate. ${ }^{27}$ Over time, however, the movements have increasingly been seen as interdependent. Human rights such as freedom of expression, the right to life, or freedom from torture, arguably provide necessary preconditions for realising labour rights. ${ }^{28}$ As a result, the status of labour rights in any country can provide an indication of the status of human rights generally. ${ }^{29}$

For some, the formulation of labour rights gives 'practical expression to a number of very important human rights'. ${ }^{30}$ In this way, the ILO's actions can be seen as 'measures for the implementation of the right to just and favourable conditions of work, affirmed by the Universal Declaration of Human Rights (UDHR) and recognised by the ICESCR ${ }^{31}$ For others, labour rights covered in the ICESCR constitute 'a summary of the ILO standards that already existed on the same subjects' such as the right to work, the right to just and favourable conditions of work, and trade union rights. ${ }^{32}$ In spite of their clear overlap, fundamental differences still exist between the two separate regimes. While human rights:

concern individuals and, arguably, achieve outcomes such as better working conditions, labour rights are more collectively oriented, and worker mobilization and negotiations processes take precedence. ${ }^{33}$

26 Kevin Kolben, 'Labor Rights as Human Rights?' (2010) 50(2) Virginia Journal of International Law 449, 453.

27 Virginia A. Leary, 'The Paradox of Workers' Rights as Human Rights' chapter 2 in Lance A. Compar and Stephen F. Diamond (eds), Human Rights, Labor Rights and International Trade (University of Pennsylvania Press, 1996) 22, 22.

28 Franz Christian Ebert and Martin Oelz, 'Bridging the gap between labour rights and human rights: The role of ILO law in regional human rights courts' (Discussion paper, International Institute for Labour Studies, $\mathrm{DP} / 212 / 2012) 2$.

29 Leary, above n 27, 22.

30 Malcolm N. Shaw, International Law (Cambridge University Press, 6th ed, 2008) 530.

31 Universal Declaration on Human Rights, GA Res 217A (III), UN GAOR, 3rd sess, 183rd plen mtg, UN Doc A/810 (10 December 1948) (UDHR).

32 C. Wilfred Jenks, 'Human Rights, Social Justice and Peace: The Broader Significance of the ILO Experience' in Asbjorn Eide and August Schou (eds) International Protection of Human Rights (Almqvist and Wicksell, 1968) 239; Hector Bartolomei de la Cruz et al., The International Labour Organization (1996) 127-129, quoted in Arne Vandaele, International labour rights and the social clause: friends or foes? (Cameron May, 2005) 147; ICESCR art 6-8.

33 Kolben, above n 26, 452 . 
Labour rights require state intervention into the private sphere. ${ }^{34}$ They offer 'mobilisation rights' by providing the right to form a collective that 'can force [employers] to negotiate work conditions against a backdrop of state-prescribed minimal standards'. ${ }^{35}$ This is in contrast to the state-individual relationship that human rights create, and even the outcomes-focused approach they entail.

\section{Is there a practical need for convergence?}

The need for human rights organisations to engage labour law was recognised by labour rights scholar Virginia Leary when she lamented their neglect of economic, social and cultural rights, which included workers' rights. ${ }^{36}$ There are clear benefits in recognising that a link exists between human rights and labour rights. Both are divided into international and regional systems, and are fragmented by different lawmakers and supervisory mechanisms. ${ }^{37}$ As a result, coherence between human rights law that touches on labour rights and corresponding ILO standards could improve how both sets of rights are implemented. ${ }^{38}$

One suggested approach is to integrate the ILO's jurisprudence (understood as its instruments and the reports of its supervisory mechanisms) into the case law of regional human rights courts. ${ }^{39}$ Domestic courts'use of international norms depends on whether they have been accepted by that state. However, domestic courts tend to use regional courts as their 'primary international law reference on human rights issues'.$^{40}$ Regional courts have not disputed the authoritative character of the ILO's supervisory mechanisms, lending support to the argument that the ILO has acquired 'a leading role regarding the shaping of regional human rights law in relation to labour standards'. ${ }^{41}$ The ratification of ILO conventions is documented as having improved labour law in a number of countries. ${ }^{42}$ The influence of the ILO's conventions on the Arab Charter of Human Rights (ACHR), ratified by Qatar and other GCC countries, is clear in the inclusion of rights relating to freedom of association, and the right to strike. ${ }^{43}$ In Qatar, this may enable domestic courts to refer to rights that are contained in instruments that Qatar has not ratified.

\footnotetext{
34 Ibid 469.

35 Ibid 472

36 Leary, above n 27, 24

37 Ebert and Oelz, above n 28,3.

38 Ibid.

39 Ibid.

40 Ibid 4.

41 Ibid 13.

42 Walter Galenson, The International Labor Organization: An American View (University of Wisconsin Press, 1981) cited in Leary, above n 27, 42.

43 Arab Charter on Human Rights 2004 [Mohammed Amin Al-Midani and Mathilde Cabanettes trans, 'Arab Charter on Human Rights 2004' (2006) 24(147) Boston University International Law Journal 147-164] art 35.
} 
A view nevertheless persists that labour rights need human rights, in theory and in practice. There is a widespread belief that norms are considered rights insofar as they are enforceable - that is, that a legal remedy is available to individuals. ${ }^{44}$ For some, the traditional sources of international labour law are insufficient for guaranteeing their enforcement. ${ }^{45}$ Yet international human rights law instruments offer little comparative advantage to international labour law. For example, even if Qatar were a party to the ICESCR, it would still not be subject to a complaints mechanism that protects the economic, social and cultural rights within that instrument. ${ }^{46}$ The practical achievements of the international labour law regime in a setting like Qatar far surpass the achievements of its human rights equivalent. This is made possible by the ILO, at the forefront of the development of international labour law.

\section{The ILO $\vee$ human rights bodies}

Whereas once, international documents were drafted with the expectation that international actors and law would not 'intervene in matters which are essentially within the domestic jurisdiction of any state', the implementation of international law and action today cannot be achieved without domestic cooperation. ${ }^{47}$ In implementing international labour law, the ILO relies on offers of help to continually exert pressure on persistent violators so that the 'virtues of reform become irresistible'. ${ }^{48}$ Workers' rights are well defined through elaboration and clarification in ILO conventions, and are subject to a stronger enforcement process that supervises their application. ${ }^{49}$

One of the biggest problems the ILO faces is in the discrepancy between ratification and implementation. ${ }^{50}$ Some see inefficient processes as having weakened the role of the ILO as a monitoring mechanism. ${ }^{51}$ As is the case with respect to human rights instruments, Qatar has not ratified many of the ILO's instruments that are

\footnotetext{
44 Vandaele, above n 32320.

45 Ibid 321.

46 Cf Human Rights Committee in ICCPR pt IV, art 28.

47 Charter of the United Nations, art 2[7]; Anne-Marie Slaughter and William Burke-White, 'The Future of International Law is Domestic (or, The European Way of Law)' (2006) 47(2) Harvard International Law Journal 328.

48 Kari Tapiola and Lee Swepston, 'The ILO and the impact of labor standards: working on the ground after an ILO Commission of Inquiry' (2010) 21(3) Stanford Law E' Policy Review 101, 114.

49 Leary, above n 27, 25.

50 Manfred Weiss, 'International Labour Standards: A Complex Public-Private Policy Mix' (2013) 29 International Journal of Comparative Law and Industrial Relations 7, 9.

51 Ibid.
} 
relevant to migrant workers. ${ }^{52}$ However, in contrast with the experience of human rights bodies, this has not prevented the ILO's supervisory system from taking action and applying pressure to Qatar and other non-party states to comply with existing standards to guarantee certain rights.

The authority of the ILO's supervisory system for international labour law is analogous with the authority given to the Human Rights Committee for international human rights law, as recognised by the International Court of Justice, which 'ascribe[d] great weight to the interpretation adopted by this independent body that was established specifically to supervise the application of [the ICCPR]'. ${ }^{53}$ The Committee of the Freedom of Association, in particular, has the authority to ensure states comply with the international labour right to freedom of association. ${ }^{54}$

Earlier this year, that committee addressed a complaint against Qatar from the International Trade Union Confederation, and confirmed that Qatar was committed to freedom of association by virtue of its ILO membership. ${ }^{55}$ The committee recommended that the government eliminate 'any restrictions placed on the freedom of association rights of migrant workers' alongside other specific recommendations. ${ }^{56}$ That Qatar had not ratified the relevant convention did not remove it from scrutiny. ${ }^{57}$ This demonstrates the organisation's preference to push for states to comply with obligations, rather than simply accept that those obligations exist. Some have even urged it to take this action-based approach further and take more local, contextual and embedded activities. ${ }^{58}$ This would see it move from a 'top-down' to a 'bottom-up' model of setting standards, in contrast with the 'top-down' approach that human rights entail. ${ }^{59}$

52 See, e.g., Private Employment Agencies Convention, 1997 (No. 181), opened for signature 19 June 1997, International Labour Conference, 85th sess (entered into force 10 May 2000); Migration for Employment Convention (Revised), 1949 (No. 97), opened for signature 1 July 1949, International Labour Conference, 32nd sess (entered into force 22 January 1952); Domestic Workers Convention, 2011 (No. 189), opened for signature 16 June 2011, International Labour Conference, 100th sess (entered into force 5 September 2013).

53 Ahmadou Sadio Diallo (Republic of Guinea v Democratic Republic of the Congo) (Judgment) [2010] ICJ Rep 32, $24[66]$.

54 Shaw, above n 30,340 .

55 Reports of the Committee on Freedom of Association, 371st report, ILO Governing Body, 320th session, agenda item 12, case no. 2988, GB.320/INS/12 (13-27 March 2014) ('Report of the Committee on Freedom of Association'); see also Fundamental Declaration:

[A]11 members, even if they have not ratified the Conventions in question, have an obligation arising from the very fact of membership in the Organization, to respect, to promote, and to realize, in good faith and in accordance with the [ILO] constitution ... namely: (a) freedom of association and the effective recognition of the right to collective bargaining ...

56 Report of the Committee on Freedom of Association para 862(b).

57 NORMLEX Information System on International Labour Standards, 'Freedom of Association and Protection of the Right to Organise Convention, 1948 (No. 87)', International Labour Organization www.ilo.org/ dyn/normlex/en/f?p=1000:11300:0::NO:11300:P11300_INSTRUMENT_ID:312232.

58 Cited in Weiss, above n 50, 12.

59 Ibid. 
The need for this was illuminated by the Qatari government's recent decision to launch its own legal investigation into migrant workers. ${ }^{60}$ The government's subsequent proposal of a number of reforms to the law, including replacing the kafala system with a system based on employment contracts, lessening exit visa requirements, applying sanctions against employers failing to meet their obligations, and creating tighter regulatory links with sending states, were all met with scepticism by prominent human rights organisations due to the continued dependency on the goodwill and cooperation of the state. ${ }^{61}$ Moving to a more 'bottom-up' approach and re-focusing the ILO on pure labour rights would allow it to further avoid over-relying on the state. This approach is even clear in the ILO's constitution, which has a tripartite structure that allows employers, workers, and governments to be represented. ${ }^{62}$ At its core, the distinction is recognition of the fact that:

$[\mathrm{t}]$ he philanthropic approach of human rights activists to labour rights is in direct contrast to an agency approach to labour rights, whereby workplace emancipation and improved working conditions are not achieved as a gift from others, but rather through individual or collective action. ${ }^{63}$

Today, Agamben's bomo sacer is the 'privileged object of the humanitarian biopolitics ... the one who is deprived of his full humanity through the very patronising way of being taken care of' ${ }^{64}$ Taking an approach centred on worker agency avoids the 'humanitarian biopolitics' that risks only entrenching migrant workers in 'bare life'. The ILO emphasises worker agency by directly engaging employers and workers, as demonstrated by the fact that its investigation of the complaint against Qatar came from a trade union federation. Although the ILO takes governments as a given, and attempts to incrementally change their behaviour towards workers, employers, and organisations, it presents issues as technical problems, created by a state's failure to apply its obligations. ${ }^{65}$ Even when it addresses the state, the ILO avoids 'raising political stakes', in the interests of efficiency, and refrains from presenting issues as serious human rights violations. ${ }^{66}$

60 'Migrant Labour in the Construction Sector in the State of Qatar', (Report, DLA Piper UK LLP, April 2014). 61 Ian Black, Owen Gibson and Robert Booth, 'Qatar promises to reform labour laws after outcry over "World Cup slaves", The Guardian (online), 15 May 2014, www.theguardian.com/world/2014/may/14/qatar-reformlabout-laws-outcry-world-cup-slaves.

62 Ian Brownlie, Principles of Public International Law (Oxford University Press, 6th ed, 2003) 531.

63 Kolben, above n 26, 478.

64 Quoted in Bülent Diken, 'From refugee camps to gated communities: biopolitics and the end of the city' (2004) 8(1) Citizenship Studies 83, 89.

65 Tapiola and Swepston, above n 48, 110.

66 Ibid. 


\section{How can this be reconciled with the ILO's move towards human rights?}

The short answer is: with difficulty and to the detriment of those it should protect. The ILO has progressively adopted a view of labour rights as human rights. This was particularly clear when it adopted its Domestic Workers Convention, 2011 No. 189 and Domestic Workers Recommendation, 2011 No. 201. ${ }^{67}$ Since it was established in 1919, the ILO has primarily focused on the labour standards of the formal sector. ${ }^{68}$ Where the informal sector was larger than the formal one, these standards had historically fallen short of protecting workers. While it convened repeatedly to set robust standards for areas of employment relevant mostly to male workers, the ILO has neglected to include the large number of mostly female and largely domestic migrant workers from their core focus. ${ }^{69}$

The 2011 standards saw the ILO target this historically marginalised category of workers to bring them into a paradigm of workplace citizenship. ${ }^{70}$ The ILO recognised the universality and urgency of these workers' needs by moving away from the abstract and undifferentiated nature of its older instruments towards more inclusive standards. ${ }^{71}$ To do this, it seemingly adopted a human rights approach, even highlighting the importance of human rights for all domestic workers. ${ }^{72}$ However, this behaviour is not exceptional for the ILO. To some extent, social concerns have inhered in the ILO since its creation in the Treaty of Versailles, where the phrase 'social justice' was used to describe its aims. ${ }^{73}$ It was once human rights became a focus of international attention, following the Second World War and the adoption of the UDHR, and the ILO became a specialised agency of the United Nations (UN), that it began to emphasise how labour rights related to human rights and social justice. ${ }^{74}$

In 1998, the ILO produced a Fundamental Declaration on Principles and Rights at Work (Fundamental Declaration) that designated the following as core labour rights:

67 Domestic Workers Convention, 2011 No. 189, opened for signature 16 June 2011, International Labour Conference, 100th sess (entered into force 5 September 2013); Domestic Workers Recommendation, 2011 No. 201, R201, International Labour Conference, 110th sess (16 June 2011).

68 Weiss, above n 50, 10.

69 Blackett, above n 5, 261.

70 Ibid 262.

71 Ibid.

72 Domestic Workers Convention, 2011 No. 189, art 3(1).

73 Treaty of Versailles, opened for signature 28 June 1919, ATS 1 (entered into force 10 January 1920) pt XIII, s 1; Leary, above n 27, 39.

74 International Labour Organization, Origins and History, ilo.org/global/about-the-ilo/history/lang--en/ index.htm; Leary, above n 27, 39 . 
- Freedom of association and the right to collective bargaining;

- The elimination of forced or compulsory labour;

- The abolition of child labour; and

- The elimination of discrimination in employment and occupation. ${ }^{75}$

With this declaration, the ILO reinforced these few categories of labour rights in the human rights corpus. ${ }^{76} \mathrm{Had}$ it taken a blanket approach to all labour rights, it may have conflated rights that are procedural, and standards that are outcomebased. ${ }^{77}$ By drawing out these four core rights, the ILO made the decision to emphasise worker agency specifically. ${ }^{78}$ However the term 'fundamental' created a tier of rights that could be categorised as civil and political, while reducing other economic rights to mere claims. ${ }^{79}$

If the ILO privileges political and civil rights, as the international human rights regime does, it risks neglecting the 'heartland of labour rights' ${ }^{80} \mathrm{~A}$ thicker, expansive account of labour law should be preferred for this reason, and labour rights in all relevant human rights instruments, and ILO conventions jurisprudence should be regarded as fundamental. ${ }^{81}$ Diluting the rights and standards at the core of the international labour law regime undermines the ILO's supervisory system, and its demonstrated benefits and achievements, and ultimately compromises worker agency.

\section{Conclusion}

There is no need for labour rights to be subsumed into the human rights corpus that arises from the international labour law regime itself. The ILO's supervisory system has independently obtained significant results for implementing labour rights, and continues to do so for migrant workers in Qatar. The organisation's recent turn to focus on migrant domestic workers in particular is a positive sign for efforts to protect workers that are so displaced and de-subjectified by the states that receive them.

75 Fundamental Declaration, art 22.

76 Kolben, above n 26, 454.

77 Brian Langille, 'Core Labour Rights-The True Story (Response to Alston)' (2005) 16 European Journal of International Law 427.

78 Ibid 431.

79 Vandaele, above n 32, 153.

80 Philip Alston and James Heenan, 'Shrinking the International Labor Code: An Unintended Consequence of the 1998 ILO Declaration on Fundamental Principles and Rights at Work?' (2004) 36 New York University Journal of International Law and Politics 221, 255-6.

81 Kolben, above n 26, 455. 
The situation of migrant domestic workers in Qatar is a clear example of the dangers of an over-reliance on state cooperation for the protection of individuals. The very invocation of human rights affirms states' power to suspend law and order, which, in the first place, ensures that the rights of man and the rights of the citizen remain separate. As a result, the international human rights regime is severely limited in what it can and cannot do, and human rights offer little to those whom the state has already suspended. Labour rights are human rights issues, but the two are not synonymous. The international labour law regime must reaffirm the pure labour law approach at its core that emphasises worker agency. Doing so offers the better approach to empower migrant domestic workers, and remove them from 'bare life'.

\section{Bibliography}

\section{Articles/books/reports}

Agamben, Giorgio, Homo Sacer: Sovereign Power and Bare Life (Stanford University Press, 1998).

Alston, Philip and James Heenan, 'Shrinking the International Labor Code: An Unintended Consequence of the 1998 ILO Declaration on Fundamental Principles and Rights at Work?' (2004) 36 New York University Journal of International Law and Politics 221.

Arendt, Hannah, The Origins of Totalitarianism (Schocken Books, 2004) 380.

'Bahrain: Abuse of Migrant Workers Despite Reforms', Human Rights Watch, 1 October 2012, www.hrw.org/news/2012/09/30/bahrain-abuse-migrantworkers-despite-reforms.

Batty, David, 'Conditions for Abu Dhabi's migrant workers "shame the west", The Guardian (online), 22 December 2013, www.theguardian.com/world/2013/ $\mathrm{dec} / 22 / \mathrm{abu}$-dhabi-migrant-workers-conditions-shame-west.

Black, Ian, Owen Gibson and Robert Booth, 'Qatar promises to reform labour laws after outcry over "World Cup slaves", The Guardian (online), 15 May 2014, www.theguardian.com/world/2014/may/14/qatar-reform-labout-lawsoutcry-world-cup-slaves.

Blackett, Adele, 'The Space Between Us: Migrant Domestic Workers as a Nexus between International Labour Standards and Trade Policy' in Daniel Drache and Les Jacobs (eds) Linking Global Trade and Human Rights: New Policy Space in Hard Economic Times (Cambridge University Press, 2014) 259. 
Brownlie, Ian, Principles of Public International Law (Oxford University Press, 6th ed, 2003).

'Building a Better World Cup: Protecting Migrant Workers in Qatar Ahead of FIFA 2022' (Report, Human Rights Watch, June 2012) 51.

Davison, William, 'Ethiopia Workers Return from Saudi Arabia Telling of Abuse', Bloomberg, 13 December 2013 www.bloomberg.com/news/2013-12-12/ ethiopian-migrant-workers-return-from-saudi-with-tales-of-abuse.html.

Diken, Bülent, 'From refugee camps to gated communities: biopolitics and the end of the city' (2004) 8(1) Citizenship Studies 83.

Ebert, Franz Christian and Martin Oelz, 'Bridging the gap between labour rights and human rights: The role of ILO law in regional human rights courts' (Discussion paper, International Institute for Labour Studies, DP/212/2012).

Ek, Richard, 'Giorgio Agamben and the Spatialities of the Camp: An introduction' (2006) Journal Compilation - Swedish Society for Anthropology and Geology.

International Labour Office, A Global Alliance Against Forced Labour: Global Report under the Follow-up to the ILO Declaration on Fundamental Principles and Rights of Work, International Labour Conference, 93rd sess (2005).

International Labour Organization, Origins and History, ilo.org/global/about-theilo/history/lang--en/index.htm.

Jenks, C. Wilfred, 'Human Rights, Social Justice and Peace: The Broader Significance of the ILO Experience' in Asbjorn Eide and August Schou (eds) International Protection of Human Rights (Almqvist and Wicksell, 1968) 239-292.

Kennedy, David, 'The International Human Rights Movement: Part of the problem?' (2002) 14 Harvard Human Rights Journal 101-126.

Kolben, Kevin, 'Labor Rights as Human Rights?' (2010) 50(2) Virginia Journal of International Law 449-484.

Langille, Brian, 'Core Labour Rights-The True Story (Response to Alston)' (2005) 16 European Journal of International Law 409.

Leary, Virginia A., 'The Paradox of Workers' Rights as Human Rights' chapter 2 in Lance A. Compar and Stephen F. Diamond, Human Rights, Labor Rights and International Trade (University of Pennsylvania Press, 1996) 22.

'Migrant Labour in the Construction Sector in the State of Qatar' (Report, DLA Piper UK LLP, April 2014). 
Mountz, Alison 'Where asylum-seekers wait: feminist counter-topographies of sites between states' (2011) 18(3) Gender, Place and Culture, 381-399.

NORMLEX Information System on International Labour Standards, 'Freedom of Association and Protection of the Right to Organise Convention, 1948 (No. 87)', International Labour Organization, www.ilo.org/dyn/normlex/en/f? p=1000:11300:0::NO:11300:P11300_INSTRUMENT_ID:312232.

Pathirana, Saroj, 'Kuwait's abused domestic workers have "nowhere to turn", $B B C$ News (online), 13 October 2010, www.bbc.com/news/world-southasia-11444167.

Pattisson, Pete, 'Revealed: Qatar's World cup “slaves”, The Guardian (online), 26 September 2013, www.theguardian.com/world/2013/sep/25/revealedqatars-world-cup-slaves.

Reports of the Committee on Freedom of Association, 371st report, ILO Governing Body, 320th session, agenda item 12, case no. 2988, GB.320/INS/12 (13-27 March 2014).

Shaw, Malcolm N., International Law (Cambridge University Press, 6th ed, 2008).

Slaughter Anne-Marie and William Burke-White, 'The Future of International Law is Domestic (or, The European Way of Law)' (2006) 47(2) Harvard International Law Journal, 327.

Tapiola, Kari and Lee Swepston, 'The ILO and the impact of labor standards: working on the ground after an ILO Commission of Inquiry' (2010) 21 Stanford Law E' Policy Review 3, 101.

'The Dark Side of Migration: Spotlight on Qatar's Construction Sector Ahead of the World Cup' (Report, Amnesty International, 2013).

Tungohan, Ethel, 'International Approaches to Governing International Migrants, Ethnicity, and Gender: An Intersectional Analysis of Migrants' Rights', in Will Kymlicka and Jane Boulden (eds), International Approaches to Governing Ethnic Diversity (Oxford University Press, 2012).

'UN expert on human trafficking calls on Oman to do more to help victims', United Nations News Centre, 8 November 2006, www.un.org/apps/news/story. asp?NewsID=20537\#.VEywwY4isWY.

Vandaele, Arne, International labour rights and the social clause: friends or foes? (Cameron May, 2005). 
Weiss, Manfred, 'International Labour Standards: A Complex Public-Private Policy Mix' (2013) 29 International Journal of Comparative Law and Industrial Relations 7.

Whyte, Jessica, 'Particular Rights and Absolute Wrongs: Giorgio Agamben on Life and Politics' (2009) 20 Law Critique 147.

\section{Cases}

Abmadou Sadio Diallo (Republic of Guinea v Democratic Republic of the Congo) (Judgment) [2010] ICJ Rep 32.

\section{Legislation}

Arab Charter on Human Rights 2004 [Mohammed Amin Al-Midani and Mathilde Cabanettes trans, 'Arab Charter on Human Rights 2004' (2006) 24(147) Boston University International Law Journal 147-164].

International Labour Organization Declaration on Fundamental Principles and Rights at Work and its Follow-up, International Labour Conference, 86th sess (18 June 1998).

Law No. 4 of 2009 Regarding Regulation of the Expatriates Entry, Departure, Residence and Sponsorship (Qatar) 29 March 2009.

Law No. 14 of 2004 On the Promulgation of Labour Law (Qatar) 19 May 2004.

\section{Treaties}

\section{Charter of the United Nations.}

Domestic Workers Convention, 2011 No. 189, opened for signature 16 June 2011, International Labour Conference, 100th sess (entered into force 5 September 2013).

Domestic Workers Recommendation, 2011 No. 201, R201, International Labour Conference, 110th sess (16 June 2011).

Forced Labour Convention, 1930 (No. 29), opened for signature 28 June 1930, International Labour Conference, 14th sess (entered into force 1 May 1932).

International Covenant on Civil and Political Rights, opened for signature 19 December 1966, 999 UNTS 171 (entered into force 23 March 1976).

International Covenant on Economic Social and Cultural Rights, opened for signature 19 December 1966, 993 UNTS 3 (entered into force 3 January 1976). 
Migration for Employment Convention (Revised), 1949 (No. 97), opened for signature 1 July 1949, International Labour Conference, 32nd sess (entered into force 22 January 1952).

Private Employment Agencies Convention, 1997 (No. 181), opened for signature 19 June 1997, International Labour Conference, 85th sess (entered into force 10 May 2000).

Treaty of Versailles, opened for signature 28 June 1919, ATS 1 (entered into force 10 January 1920).

Universal Declaration on Human Rights, GA Res 217A (III), UN GAOR, 3rd sess, 183rd plen mtg, UN Doc A/810 (10 December 1948). 
This text is taken from The ANU Undergraduate Research Journal, Volume Seven, 2015, edited by Daniel McKay, published 2016 by ANU eView, The Australian National University, Canberra, Australia. 